\title{
Fresh Groundwater Resources in Georgia and Management Problems
}

\author{
George Gaprindashvili1,2, Merab Gaprindashvili1 \\ ${ }^{1}$ Department of Geology, National Environmental Agency, Ministry of Environment and Natural Resources \\ Protection, Tbilisi, Georgia \\ ${ }^{2}$ Vakhushti Bagrationi Institute of Geography, Ivane Javakhishvili Tbilisi State University, Tbilisi, Georgia \\ Email: gaprindashvili.george@gmail.com, george.gaprindashvili@tsu.ge
}

Received 12 May 2014; revised 8 June 2014; accepted 2 July 2014

Copyright (C) 2014 by authors and Scientific Research Publishing Inc.

This work is licensed under the Creative Commons Attribution International License (CC BY). http://creativecommons.org/licenses/by/4.0/

(c) (i) Open Access

\begin{abstract}
As it is known fresh water represents conditioned factor for human body's life. That's why the superiority of drinking water is recognized as human body's priority according to the international declarations. World is experiencing deficit of quality water. Natural Disasters caused by the pollution of the fresh ground water is also very painful and acute, because it needed more time, more material and financial means for the liquidation of their results, and what the most important practically is, it is impossible to renew the initial natural conditions completely. All these conditions that the rational use of fresh ground water passed by the interests of separate countries and became worldwide, international problem-fresh water became as considerable raw material for the worlds import and export. Future prognosis is disturbing-according to the data of UN for 2025 year $2 / 3$ of world population will be under the water deficit conditions. Above-mentioned shows how important fresh water is for humanity. Below we present briefly review about the situation of fresh ground water resources and the analysis of the problems in transboundary artesian basins of Georgia.
\end{abstract}

\section{Keywords}

Groundwater, Transboundary, Artesian Basins, Georgia, Quality Drinking Water, Hydrogeology

\section{Introduction}

Georgia, in spite of lacking of territory is distinguished for its geological-geomorphological diversity, also for wide specter of climatic landscape, from the beginning of Caucasus Mountains constant glacier zone, to the end of subtropical coastal strip. Exactly the mentioned provisions determine formation and location aspects of min- 
erals, including groundwater. Below it is presented the brief description of the mentioned provisions.

\section{Study Area}

Georgia, in spite of lack of territory is distinguished for its geological-geomorphological diversity, also for wide specter of climatic landscape. Georgia is situated in the west part of South Caucasia. To the north and the south it is bounded by mountainous systems of Big and Small Caucasus, to the west-the Black Sea and to the eastdepression of River Kura (Figure 1). West Georgian climate region is characterized with large number of precipitation, annual average number is between $800 \mathrm{~mm}$ and $2500 \mathrm{~mm}$, but East Georgian climate region is characterized with proximate low precipitation—from $300 \mathrm{~mm}$ to $1700 \mathrm{~mm}$ in a year. In formation of groundwater, the important role Play Rivers, lakes and reservoirs, with which Georgia is one of the richest countries in the world. Geological structure of the territory plays one of the major roles in the formation of minerals, including groundwater. Georgia's underground hydrosphere has a full spectrum of both the classic and rare hydrogeological systems and environments including anomalies. This is the reason for the presence of groundwater belonging to the main, rare and unique categories (fresh, mineral and thermal). According to the hydrogeological zones, in Georgia there are artesian basins and pressured (confined) groundwater systems, which contain porous, fractured, and fractured/karstic aquifers. They are abundant, renewable and of high quality.

Georgia is rich in mineral and raw materials for creating strong base for the development of agriculture and industry development. The mineral resources of Georgia such as manganese, coal, oil and gas, zinc, arsenic have the important place with hydro energetical resources [1].

The fresh groundwater place the important role among the water recourses of Georgia. Their existing is considerably connected to the development of industry and agriculture, also with water supply issue of populated area. On the bases of mineral waters a lot of worldwide health resorts such as Borjomi, Tskhaltubo are functioning. The country recourses are rich with thermal waters, which are widely used for balneological purposes. According to the all above mentioned the rational assimilation and protection of fresh groundwater in Georgia have the world wide importance of the state, and presents as the guaranty of success, and safety of country's economic activities. According to the mineralization and temperature parameters groundwater is generally divided into the following groups: 1) Fresh drinking waters (mineralization not exceeding $1.0 \mathrm{~g} / \mathrm{l}$ ); 2) Mineral waters (mineralization over $1.0 \mathrm{~g} / \mathrm{l})$; 3) Thermal waters-healing $\left(20^{\circ} \mathrm{C}-35^{\circ} \mathrm{C}\right)$, Geothermal $\left(40^{\circ} \mathrm{C}-108^{\circ} \mathrm{C}\right)[2]$.

The Alazani Artesian Basin takes its name from the Alazani River, which flows in the eastern part of the country in a northwest-southeast direction. It is the main tributary of the largest river of Georgia—the Kura.

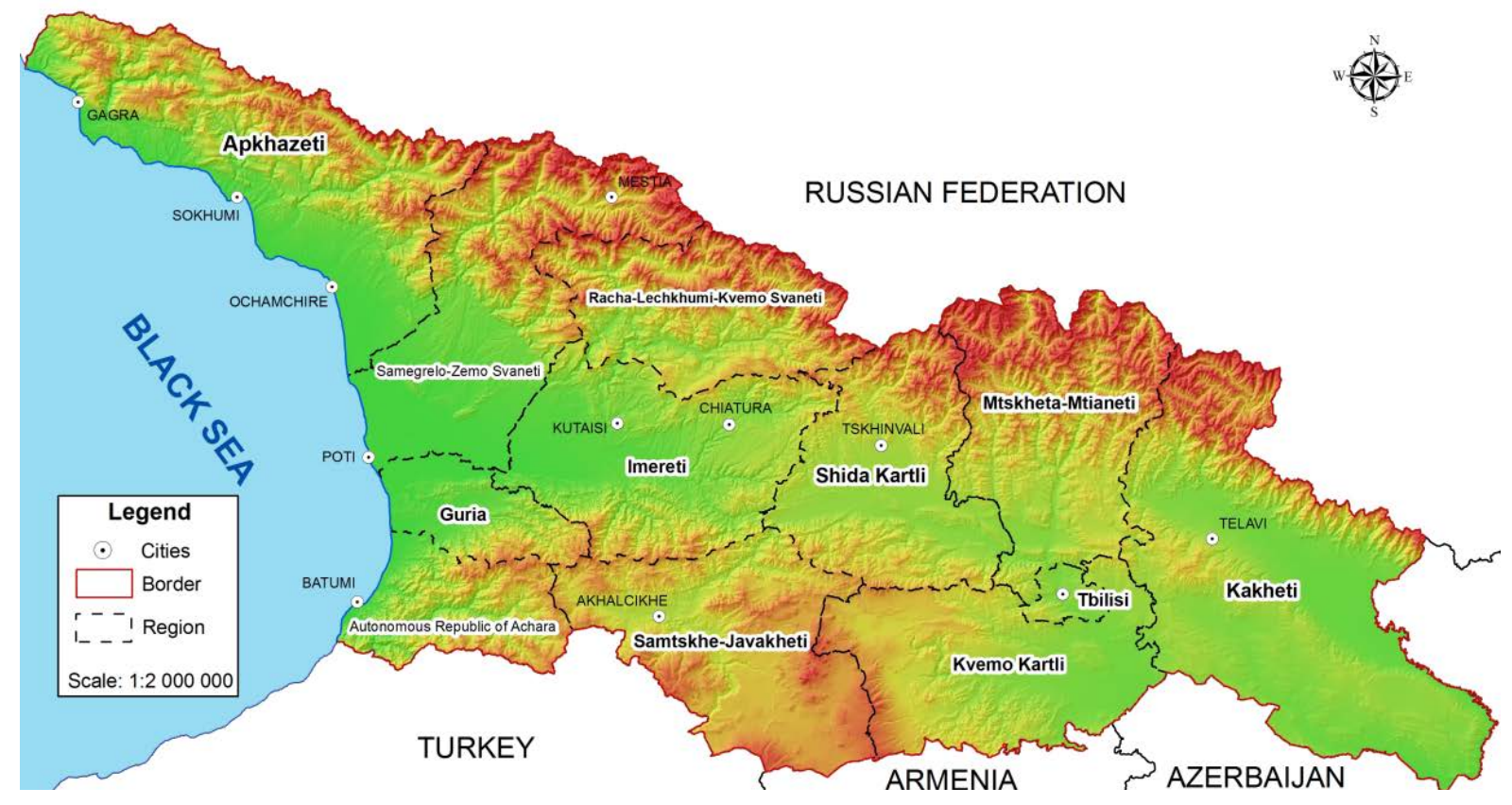

Figure 1. Map of Georgia. 
Part of its course forms the border between Georgia and Azerbaijan. The Alazani originates in the Greater Caucasus, south of the main ridge. The hydrogeological conditions of the Alazani-Agrichai basin are given by the position of the Alazani Valley near the mountains, the thickness of the aquifer layers and its alternation with impermeable layers and the significant elevation of the valley edges against the valley base with a relatively small river gradient. An important role is played by the existence of dense vegetation cover on the raised edges of the valley and on the slopes of the Kakheti Ridge and the Main Caucasian ridge. Another factor influencing the hydrogeology of the structure is strong infiltration of surface water from left-bank and right-bank tributaries of the River Alazani into the Pre-Quaternary and Quaternary sediments. In addition, an important role is played by the layers of the Alazani series, which are exposed by erosion allowing increased infiltration from both the rivers and atmospheric precipitation. The main artesian aquifers are located into the quaternary sediments and the sediments of the Alazani series. Besides these, there are also less productive aquifers in the Quaternary alluvial sediments and prolluvial and recent alluvial sediments [3].

\section{Materials}

Natural recourses of fresh ground water in Georgia compile $573 \mathrm{~m}^{3} / \mathrm{sec}$ (49.5 million $\mathrm{m}^{3}$ in day-night) and with its side it is redistributed in the 4 big hydro-geological systems:

1) $295 \mathrm{~m}^{3} / \mathrm{sec}$ (25.5 million $\mathrm{m}^{3} /$ day-night) comes on big Caucasus wrinkled water stand system;

2) $165 \mathrm{~m}^{3} / \mathrm{sec}$ (14.3 million $\mathrm{m}^{3} /$ day-night) comes on south Caucasus artesian basin;

3) $54 \mathrm{~m}^{3} / \mathrm{sec}$ (4.67 million $\mathrm{m}^{3} /$ day-night) comes on small Caucasus water stand basin;

4) $59 \mathrm{~m}^{3} / \mathrm{sec}$ (5.1 million $\mathrm{m}^{3} /$ day-night) comes on Artvin-Bolnisi Hydrogeological massive [4].

Territorially fresh groundwater recourses are distributed unequally (Figure 2). Particularly: 62\% comes on West Georgia, East Georgia-25\% and 13\% comes on South Georgia. It must be mentioned the high quality of drinking water in this part of Georgia (South Georgia), which is the one of the main alternative supply for Tbilisi.

Fresh groundwater resources distributed distinctly (unequally). To the scale of the country circulation length of the cold (average $20^{\circ} \mathrm{C}$ ) groundwater fluctuates from several ten meters until 500 meters and on the whole it changes between 100 - 300 meters. Thus we can conclude, that formation of fresh groundwater natural recourses clearly expresses as territorially (regional), as vertical and hydro-geological zonation.

For the future perspective demand for fresh drinking water for the whole Georgia compiles $60 \mathrm{~m}^{3} / \mathrm{sec}$ (with the norm of 500 liter water for one person in family). In spite of this according to the current norms, exploitation resources of fresh groundwater must not be higher than half of their resources. So in Georgia's case it must not be higher than $286 \mathrm{~m}^{3} / \mathrm{sec}$. It is clearly shown that Georgia has excess exploitation supply about $226 \mathrm{~m}^{3} / \mathrm{sec}$. Here we would like to mention, that for country's sustainability, for ensuring with water the populated areas and strategic objects, it could be selected the following resources of ground waters: 1) Seven hydro geological strategic structure (artesian basin), reserve—45.3 $\mathrm{m}^{3} / \mathrm{sec}$; 2) Six strategic reserves resource, supply—22.2 $\mathrm{m}^{3} / \mathrm{sec}$; 3) Eleven reserves, protected in natural conditions, for using in special situations, five in Eastern part of Georgia and six in Western part of Georgia [5].

As it was mentioned above there is the deficit of quality drinking water in Georgia and therefore it is possibility that drinking water deficit should become reason of big social dissatisfaction with its negative results. This problem is more acute and strained in the assimilation conditions of fresh ground water from artesian basins existing in transboundary zone, because in such zones there is not rare such hydro-geological situation, when the area of groundwater feed and formation is in the area of one state and the load-shedding area is in another state, or on the contrary.

It could be noted that fresh water existing in the country is distinguished with high quality, best drinking features and rarely with the medical features. We should also mention one circumstance. Notwithstanding, Georgia is rich with underground water resources, world global warming will make negative effect on regimes of underground water, especially in the East Georgia. It is knows that Main source of Groundwater is precipitation, despite that in the last period it is observed precipitation deviation from annual norm caused by global climate change, although the regime of precipitation has been violated and in most cases it is heavy rain, it is unable to complete leachate through the soil and mostly it is superficial. Also melting the glaciers are very intensive; glaciers are one of the sources of groundwater forming. Hence, we will have to make complex works in order to develop the effective arrangements for course-development of the global warming processes and softening their results 


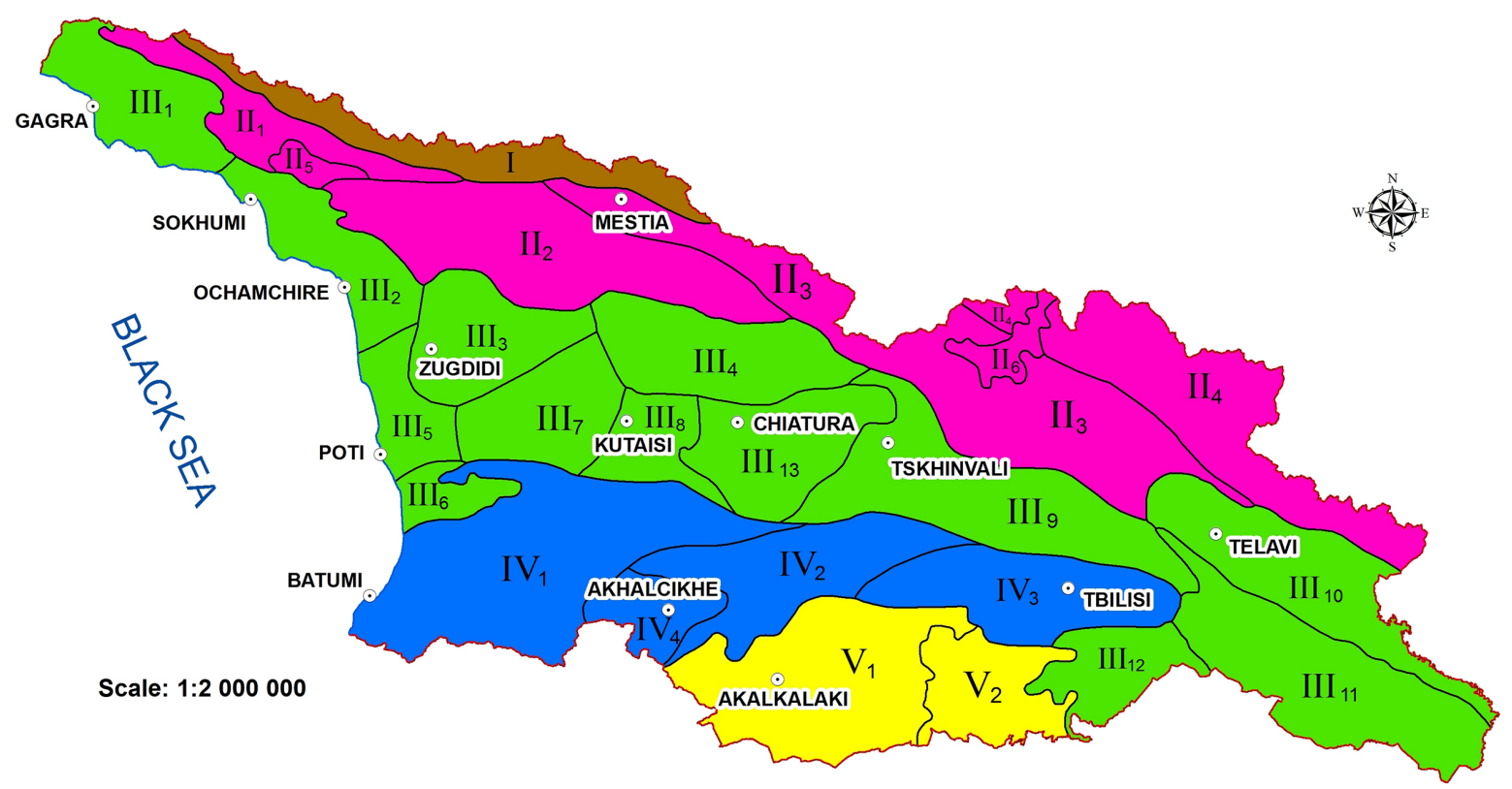

\begin{tabular}{|c|c|c|c|}
\hline \multicolumn{2}{|r|}{ Hydrogeological Region } & \multicolumn{2}{|r|}{ Hydrogeological district } \\
\hline I & $\begin{array}{l}\text { Great Caucasus Cristal } \\
\text { Substrate groundwater zone }\end{array}$ & & \\
\hline \multirow{6}{*}{ II } & \multirow{6}{*}{$\begin{array}{l}\text { Pressured Water System Zone } \\
\text { of Great Caucasus Southern } \\
\text { Slope }\end{array}$} & $\mathrm{II}_{\mathbf{1}}$ & Abkhazian fractured pressured water system \\
\hline & & $\mathrm{II}_{2}$ & Svanetian crack pressured water system \\
\hline & & $\mathbf{I}_{\mathbf{3}}$ & $\begin{array}{l}\text { Mestia-Tianeti fractured and fractured/karstic pressured } \\
\text { systems }\end{array}$ \\
\hline & & $\mathrm{II}_{4}$ & Kazbegi-Mtatusheti fractured pressured system \\
\hline & & IIt5 & Crack groundwater district of Kelasuri crystal massive \\
\hline & & $\mathbf{l l}_{\mathbf{s}}$ & Fractured groundwtaer district of Keli-Kazbegi lava formation \\
\hline \multirow{13}{*}{ III } & \multirow{13}{*}{$\begin{array}{l}\text { Georgian belt Artesian basin } \\
\text { zone }\end{array}$} & $\mathrm{III}_{1}$ & Fractured and fractured/karstic artesian basin of Bzipi \\
\hline & & $\mathrm{III}_{2}$ & Porus, fractured and fractured/karstic artesian basin of Kodori \\
\hline & & $\mathrm{III}_{3}$ & Fractured and fractured/karstic artesian basin of Samegrelo \\
\hline & & $\mathrm{III}_{4}$ & $\begin{array}{l}\text { Fractured and fractured/karstic artesian basin of } \\
\text { Racha-Lechkhumi }\end{array}$ \\
\hline & & $\mathrm{III}_{5}$ & Porus, fractured and fractured/karstic artesian basin of Kolkheti \\
\hline & & $\mathrm{III}_{6}$ & Porus and fractured water artezian basin of Guria \\
\hline & & $\mathrm{III}_{7}$ & $\begin{array}{l}\text { Porus, fractured and fractured/karstic artesian basin of } \\
\text { Tskaltubo }\end{array}$ \\
\hline & & $\mathrm{III}_{3}$ & Porus, fractured and fractured/karstic artesian basin of Argveti \\
\hline & & Ill9 & Porus, fractured and fractured/karstic artesian basin of Kartli \\
\hline & & $\mathrm{III}_{10}$ & Porus, fractured and fractured/karstic artesian basin of Alazani \\
\hline & & $\mathrm{III}_{11}$ & Porus and fractured water artesian basin of lori-Shiraki \\
\hline & & $\mathrm{III}_{12}$ & $\begin{array}{l}\text { Porus and fractured water artesian basin of Marneuli- } \\
\text { Gardabani }\end{array}$ \\
\hline & & $\mathrm{III}_{13}$ & $\begin{array}{l}\text { Fractured and fractured/karstic artesian water basin of Dzirula } \\
\text { crystal massive }\end{array}$ \\
\hline \multirow{4}{*}{ IV } & \multirow{4}{*}{$\begin{array}{l}\text { Pressured water systems of } \\
\text { Adjara-Trialeti fold mountain } \\
\text { zone }\end{array}$} & $I_{1}$ & Fractured pressured water system of Achara-Imereti \\
\hline & & $\mathrm{IV}_{2}$ & $\begin{array}{l}\text { Fractured and fractured/karstic pressured water system of } \\
\text { Trialeti }\end{array}$ \\
\hline & & $I_{3}$ & $\begin{array}{l}\text { Fractured and fractured/karstic pressured water system of } \\
\text { Tbilisi }\end{array}$ \\
\hline & & $I_{4}$ & Fractured water artesian system basin of Akhaltsikhe \\
\hline V & Artvini-Bolnisi belt zone & $\mathbf{V}_{1}$ & Fractured water system district of Akhalkalaki lava sheet \\
\hline
\end{tabular}

Figure 2. Hydrogeological zoning map of Georgia. 
and improving the present natural conditions in this region.

\section{Results and Discussions}

In case of Georgia, problems with Russia Federation are less, because the border of this 2 country practically coincides with big Caucasus ridge, that's why groundwater overflow has the less scale. There are situated 3 big Hydro-geological structure-Artesian basins of Alazani, Iori and Marneuli-Gardabani within the Azerbaijan border zone. Hydro-geological researches conducted in last period, demonstrated that fresh groundwater is overflowing from the area of Georgia to the area of Azerbaijan [6]. There are also few difficulties with the Turkey. Border between 2 countries (Georgia and Turkey) goes between the Caucasus system and Samckhe-Javakheti Hydrogeological massive. Because of different reasons this region is less studied and researched with the hydrogeological view and that's why it is abstained (refrain) for evaluating. As for the Armenia, the state border goes on the center of Hydrogeological system of Samckhe-Javakheti highland. The Hydrogeological picture shows that fresh groundwater have two-way movement, as from Georgia to Armenia, also on the contrary [7].

The issue of the proper use, development and protection of groundwater resources is one of the highest priorities of Georgia's economy. Management of groundwater requires precise knowledge of its sources (aquifers), usable quantity and quality. Monitoring of Georgia's most important aquifers started many years ago and has provided large amounts of data. This was interrupted at the beginning of the 1990s by the internal political developments in the country. It is currently one of the main priorities of the Alazani-Agrichai region because it is a border area and in addition to the Georgian population neighboring Azerbaijan also uses the water. Due to the high quality of the drinking water resource the proper monitoring of groundwater is an important task [3].

\section{Conclusion}

Follow from above mentioned, it is considered that it is inevitable to conduct hydrogeological researches with the border countries of Georgia by common methodic along the border zone and on its base arrange hydro monitoring observation network for carrying out together future monitoring researches. It should be mentioned that the regime of ground water is connected with surface water regime and the rational assimilation of the ground water should be realized complexly, according to the scheme this will indisputably conduce to remove the tensity in the region caused by different reasons, to stabilize the peace and maybe considered as one of the important political decisions.

\section{Acknowledgements}

The authors would like to thank National Environmental Agency of Ministry of Environment and Natural Resources Protection of Georgia for providing various datasets used in this study.

\section{References}

[1] Hydrogeology of USSR (1970) Monograph. USSR, Moscow, 299-335.

[2] (2011) National Report on the State of the Environment of Georgia (2007-2009). Ltd Tori Plus, Tbilisi, 57-61.

[3] (2013) Report of Pilot Project for Reactivation of Groundwater Level and Quality Monitoring Network in AlazaniAqrichai Aquifer. The Ministry of Industry and Trade of the Czech Republic, Czech Development Cooperation, National Environmental Agency, 9-14.

[4] Kharatishvili, L. (2009) Fresh Groundwater of Georgia (Resources, Mastering, Defense). Collection, Tbilisi, 12-23.

[5] (2000) Information Bulletin of the Ecologic Situation of Underground Hydrosphere, Study and Prognosis of the Hazardous Geological Processes. Tbilisi, 10-15.

[6] Buachidze, I. and Zedgenidze, S. (1985) Hydrogeology and Perspectives for Usage of Groundwater of Alazani-Agrichai Artesian Basin. Tbilisi, 56-86.

[7] Gaprindashvili, M. (2010) Fresh Ground Water Resources in Georgia and Management Problems of the Transboundary Artesian Basins. International Conference “Transboundary Aquifers: Challenges and New Directions” (ISARM2010), Paris, 6-8 December 2010. 
Scientific Research Publishing (SCIRP) is one of the largest Open Access journal publishers. It is currently publishing more than 200 open access, online, peer-reviewed journals covering a wide range of academic disciplines. SCIRP serves the worldwide academic communities and contributes to the progress and application of science with its publication.

Other selected journals from SCIRP are listed as below. Submit your manuscript to us via either submit@scirp.org or Online Submission Portal.
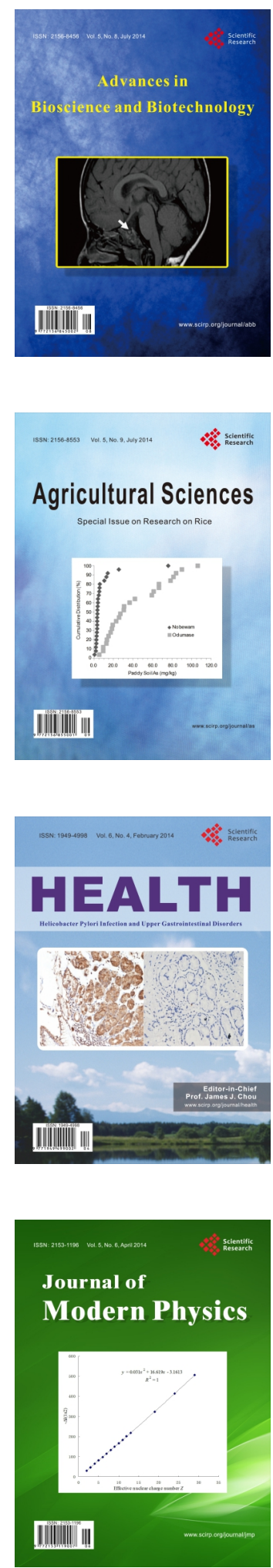
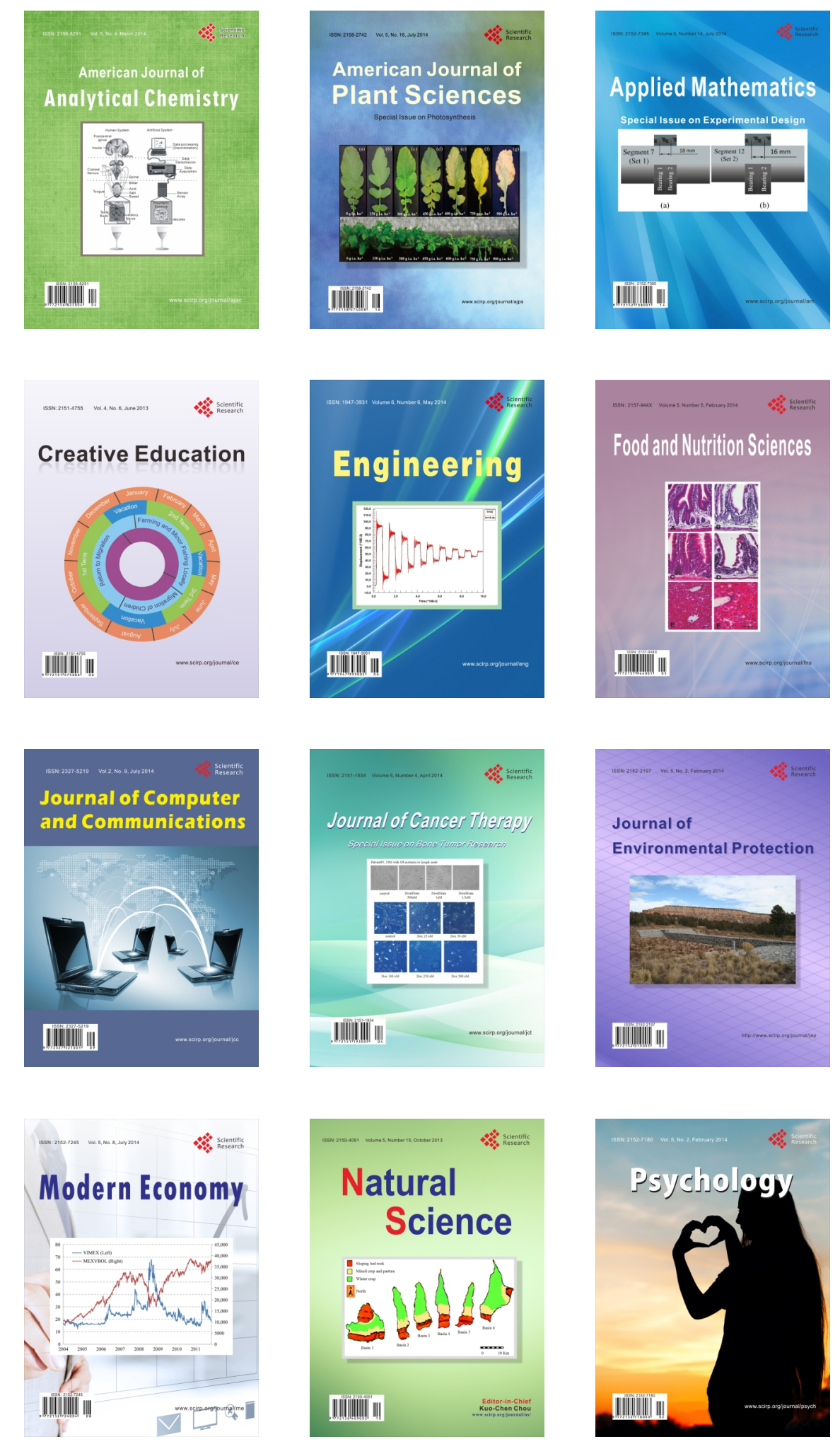